\title{
Torsion Dynamometer Application for Detecting Water Was Contaminated by Detergent
}

\author{
Rakha Saputra", Gusfianang Haryarta ${ }^{* *}$, Frida Agung Rakhmadi**** \\ Physics Department, Faculty of Science and Technology, UIN Sunan Kalijaga \\ Jl. Marsda Adisucipto No 1 Yogyakarta 55281, Indonesia. Tel. +62-274-540971, Fax. +62-274-519739 \\ Email: saputra.rakha.yunus@gmail.com*, gusfianangharyarta@gmail.com ${ }^{* *}$, frida.rakhmadi@uin-suka.ac.id ${ }^{* * *}$
}

\begin{abstract}
Research on the Torsion Dynamometer application to water was contaminated by detergent has been carried out. This research aims to develop alternative methods for detecting water was contaminated by detergent. This research is conducted in three stages, including preparation of tools and materials, data collection, and data processing. The results of this research indicate water was contaminated by detergent has the characteristics of surface tension $\gamma=\left(0,256 \times 10^{-1} \pm 1,354 \times 10^{-4}\right) \mathrm{N} / \mathrm{m}$ while, normal water has the characteristics of surface tension $\gamma=\left(0,490 \times 10^{-1} \pm 1,687 \times 10^{-4}\right) \mathrm{N} / \mathrm{m}$. Therefore, Torsion Dynamometer can be used as an alternative method to distinguish between water was contaminated by detergent and normal water.
\end{abstract}

Keywords: Detecting, Detergent, Surface tension, Torsion dynamometer

\section{INTRODUCTION}

Water pollution is currently no longer new and various efforts are made by the government and environmentalists from the community to prevent and improve water quality, especially in rivers because river water can be used as an indicator of water quality in community wells. Water from the river will be absorbed through the pores of the soil and enter the soil layer that is stored in water where the water is dug to be used as water consumed by residents.

River water contaminated with detergent waste will pollute the well water of residents near the river. Detergent water that pollutes the river water is caused by the discharge of used water for washing clothes. Rivers contaminated with detergent can usually be recognized by the appearance of foam which is quite a lot and difficult to lose, even though the water looks clear but the water is actually contaminated by detergent.

The above events have raised questions such as how to detect whether the water is contaminated with detergent or not. The easiest way to test for detergents contained in water is to check the $\mathrm{pH}$ value. The $\mathrm{pH}$ value will provide information in the form of the value of the level of alkalinity and acidity of a substance (water). Water containing detergent has a $\mathrm{pH}$ value $>7$, this value provides information that water containing detergent is alkaline.

However, there are other ways to detect water polluted by detergent, that is by measuring the surface tension of the liquid. Each liquid has a different surface tension value. As in the surface tension table for some liquids.

Surface tension can be measured using a device called the Torsion Dynamometer. The Torsion Dynamometer is a surface tension measuring instrument using the principle of an upward lift force where this force is to release the liquid surface ring which will find its surface tension value, to find the surface tension value of the upward force data must be treated first using the surface tension equation.

Table 1. Description of Mikrajuddin Abdullah (2016) on surface tension.

\begin{tabular}{ll}
\hline Liquid & Surface Tension $(\mathbf{N} / \mathbf{m})$ \\
\hline Mercury $\left(20^{\circ} \mathrm{C}\right)$ & 0,440 \\
Alcohol $\left(20^{\circ} \mathrm{C}\right)$ & 0,023 \\
$\mathrm{H}_{2} \mathrm{O}\left(0^{\circ} \mathrm{C}\right)$ & 0,076 \\
$\mathrm{H}_{2} \mathrm{O}\left(20{ }^{\circ} \mathrm{C}\right)$ & 0,072 \\
$\mathrm{H}_{2} \mathrm{O}\left(100{ }^{\circ} \mathrm{C}\right)$ & 0,059 \\
Benzen $\left(20{ }^{\circ} \mathrm{C}\right)$ & 0,029 \\
Liquid $\mathrm{O}_{2}\left(-193^{\circ} \mathrm{C}\right)$ & 0,016 \\
\hline
\end{tabular}

\section{MATERIALS AND METHODS}

\section{Tools and Materials}

Table 2. Tools and materials.

\begin{tabular}{lll}
\hline No & Tools and Materials & Total \\
\hline 1 & Torsion Dynamometer & 1 \\
2 & Tripod Base & 1 \\
3 & Statif & 1 \\
4 & Ring d = $\mathrm{cm}$ & 1 \\
5 & Beaker glass & 2 \\
7 & Water & $390 \mathrm{ml}$ \\
8 & Detergent & \\
\hline
\end{tabular}

\section{Procedures}

Preparation of tools and materials: 


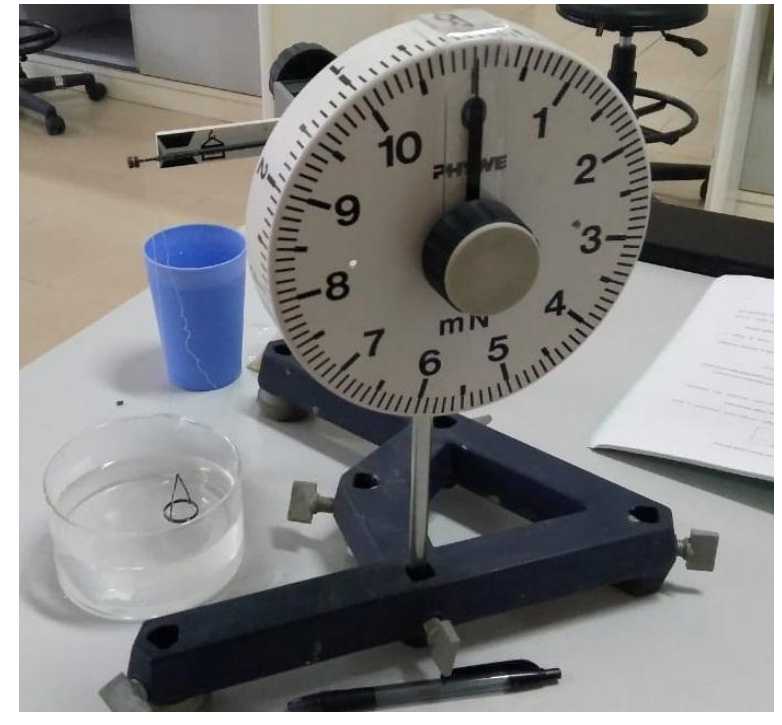

Figure 1. Photo of team practicum fisika dasar (2016) on torsion dynamometer.

\section{Data Retrieval}

Table 3. Data Retrieval Results Lifting Force on the Liquid Surface Uses the Torsion Dynamometer.

\begin{tabular}{lll}
\hline No. & \multicolumn{1}{c}{$\mathbf{F}\left(\mathbf{1 0}^{-\mathbf{3}} \mathbf{N}\right)$} \\
\cline { 2 - 3 } & Normal Water & $\begin{array}{l}\text { Water was Contaminated by } \\
\text { Detergent }\end{array}$ \\
\hline 1 & 3.10 & 1.64 \\
2 & 3.11 & 1.63 \\
3 & 3.05 & 1.65 \\
4 & 3.03 & 1.6 \\
5 & 3.04 & 1.6 \\
6 & 3.08 & 1.61 \\
7 & 3.06 & 1.57 \\
8 & 3.13 & 1.61 \\
9 & 3.07 & 1.6 \\
10 & 3.11 & 1.57 \\
\hline
\end{tabular}

\section{Method of Data Analysis}

The data obtained from the measurement above is then calculated the value of the surface tension using the equation (Tim Praktikum Fisika Dasar, 2017):

$$
\gamma=\frac{\boldsymbol{F}}{l}
$$

Explanation :

$\mathrm{F}=$ force by the surface of the fluid $(\mathrm{N})$;

$l=$ the length of the contact line between the surface of the fluid and solid (m);

$\gamma=\mathrm{a}$ constant known as the surface tension of the fluid (N/m). (Mikrajuddin Abdullah, 2016)

Then after obtaining the data, then look for the average value (Xmean) dan and the error value $(\Delta X)$, by using the equation (Morris and Langari, 2012):

$$
\gamma \text { mean }=\left(\sum_{i=1}^{n} \gamma_{n}\right) /(n) \quad \Delta \gamma=\sqrt{\left(\sum_{i=1}^{n} \gamma_{n}-\gamma \text { mean }\right) /(n(n-1))}
$$

Comparison of the average value ymean and error value $(\Delta \gamma)$ can be used to calculate the percentage value of accuracy, the following is the equation (Tim Praktikum Fisika Dasar, 2016) :

$$
\% \text { Accuracy }=100 \%-\left(\frac{\Delta y}{\text { ymean }} \times 100 \%\right)
$$

\section{RESULTS AND DISCUSSION}

\section{Results}

Method of data analysis is used to process data, so as to provide information in the form of the value of each surface tension from normal water and water is contaminated by detergent. The results of the experiments carried out and then performed calculations obtained the value of surface tension in normal water and detergent water, the results of which

\begin{tabular}{|c|c|c|c|c|c|c|}
\hline \multirow[t]{2}{*}{ No. } & \multicolumn{2}{|c|}{$F\left(10^{-3} N\right)$} & \multicolumn{2}{|l|}{$\mathrm{y}(\mathrm{N} / \mathrm{m})$} & \multicolumn{2}{|l|}{$\Delta \mathrm{y}(\mathrm{N} / \mathrm{m})$} \\
\hline & $\begin{array}{l}\text { normal } \\
\text { water }\end{array}$ & $\begin{array}{l}\text { water was } \\
\text { contaminated by } \\
\text { detergent }\end{array}$ & $\begin{array}{l}\text { normal } \\
\text { water }\end{array}$ & $\begin{array}{l}\text { water was contaminated } \\
\text { by detergent }\end{array}$ & $\begin{array}{l}\text { normal } \\
\text { water }\end{array}$ & $\begin{array}{l}\text { water was } \\
\text { contaminated by } \\
\text { detergent }\end{array}$ \\
\hline 1 & 3,10 & 1,64 & 0,0493631 & 0,02611465 & 0,0001687 & 0,0001354 \\
\hline 2 & 3,11 & 1,63 & 0,0495223 & 0,02595541 & & \\
\hline 3 & 3,05 & 1,65 & 0,0485669 & 0,02627389 & & \\
\hline 4 & 3,03 & 1,6 & 0,0482484 & 0,02547771 & & \\
\hline 5 & 3,04 & 1,6 & 0,0484076 & 0,02547771 & & \\
\hline 6 & 3,08 & 1,61 & 0,0490446 & 0,02563694 & & \\
\hline 7 & 3,06 & 1,57 & 0,0487261 & 0,025 & & \\
\hline 8 & 3,13 & 1,61 & 0,0498408 & 0,02563694 & & \\
\hline 9 & 3,07 & 1,6 & 0,0488854 & 0,02547771 & & \\
\hline 10 & 3,11 & 1,57 & 0,0495223 & 0,025 & & \\
\hline Mean & 3,078 & 1,608 & 0,0490127 & 0,0256051 & & \\
\hline
\end{tabular}
are shown in Table 4.

Table 4. Surface tension in normal water and polluted water. 
The surface tension results table above is then plotted using a comparison graph between the normal surface tension of water and water was contaminated by detergent. The graph can be seen in the graph below.

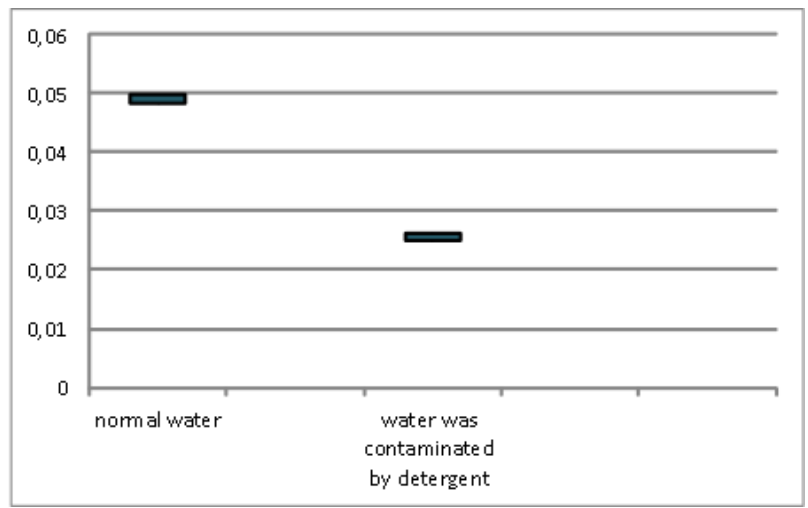

Figure 2. Comparison of surface tension graphs on normal water and water was contaminated by detergent.

\section{Discussion}

The results of this research indicate water was contaminated by detergent has the characteristics of surface tension $\mathrm{\gamma} \pm \Delta \mathrm{y}=\left(0,256 \times 10^{-1} \pm 1,354 \times 10^{-4}\right) \mathrm{N} / \mathrm{m}$ while, normal water has the characteristics of surface tension $\mathrm{\gamma} \pm \Delta \mathrm{\gamma}=\left(0,490 \times 10^{-1} \pm 1,687 \times 10^{-4}\right) \mathrm{N} / \mathrm{m}$. Both values have different values and no slices occur. Experimental data of $\mathrm{F}$ value measured on water was contaminated by detergent with $\mathrm{F}$ values measured in normal water showing differences that were not mutually sliced. F value in water was contaminated by detergent smaller than $\mathrm{F}$ value in normal water. The difference in the value of $F$ affects the different surface tension values $\mathrm{y}$.

Then, by comparing $\mathrm{y}$ and $\Delta \mathrm{\gamma}$, the water was contaminated by detergent had $\%$ accuracy $=99.477 \%$ while, normal water had \% accuracy $=99.655 \%$. This percentage strengthens that the Torsion Dynamometer device can be used properly to detect surface tension of various liquids. So that the experimental data obtained can be said to have high accuracy data. This high percentage of accuracy strengthens that the Torsion
Dynamometer tool can be used to detect surface tension of various liquids.

Therefore, the characteristics of surface tension of the water was contaminated by detergent and normal water is different, so the Torsion Dynamometer can be used as an alternative method for detecting surface tension. The difference in data results from the value of $\mathrm{F}$ and surface tension $\mathrm{\gamma}$, then plus with a high percentage of accuracy from the data obtained, this is more convincing that the Torsion Dynamometer can be used as an alternative method to measure the surface tension of the liquid. So that the tool can be used as an alternative method to detect the water was contaminated by detergent.

\section{CONCLUSIONS}

Torsion Dynamometer has been applied to detect water was contaminated by detergent in terms of its surface tension value. The results of the application found that the characteristics of normal water surface tension with water was contaminated by detergent were different, it can be concluded that this tool could be used as an alternative method to detect water was contaminated by detergent through its surface tension.

\section{ACKNOWLEDGEMENTS}

We present this article to Allah SWT as a manifestation of our gratitude to Allah SWT who has given us the opportunity and ability to develop knowledge for the advancement of science in the homeland, NKRI

\section{REFERENCES}

Abdullah, Mikrajuddin. 2016. Fisika Dasar I. ITB, Bandung. Morris, Alan S; Langari, Reza. 2012. Measurement and Instrumentation : Theory and Application. Elsevier, Amsterdam. Tim Praktikum Fisika Dasar. 2016. Modul Praktikum Fisika Dasar I. UIN Sunan Kalijaga, Sleman.

Tim Praktikum Fisika Dasar. 2017. Modul Praktikum Fisika Dasar I. UIN Sunan Kalijaga, Sleman. 
THIS PA GE INTENTIONALLY LEIT BLANK 